Arch. Met. Geoph. Biokl., Ser. B, 20, 261-267 (1972)

(C) by Springer-Verlag 1972

$551.558 .1: 551 . .588 .7$

Department of Geography, University of Michigan, Ann Arbor, Michigan, U.S.A.

\title{
The Simulation and Implications of Thermal Plumes Produced by Arctic Construction in Smooth Terrain
}

\section{Sam I. Outcalt}

\section{With 1 Figure}

Received April 3, 1972

\section{Summary}

In smooth snow covered Arctic terrain human construction produces extreme local variations in the aerodynamic roughness length. These features have been identified on thermal imagery and simulated on a digital computer. The analysis of these features provides a powerful tool for (1) assessing the spatial-temporal integrity of meteorological sites, (2) identifying cultural features in snow covered flat terrain in the relatively low resolution thermal imagery which will be acquired from spacecraft in the next decade, and (3) assessing and attenuating the environmental impact resulting from Arctic construction.

\section{Zusammenfassung}

Simulierung und Umwelteinfluß der durch Bauten in ebenem Gelände in der Arktik hervorgerufenen Thermik

Auf glattem, schneebedecktem Terrain der Arktik werden durch Bauten extreme lokale Änderungen in der aerodynamischen Bodenrauhigkeit hervorgerufen. Dieser Effekt konnte sowohl auf Temperaturabbildungen als auch durch numerische Modellrechnungen nachgewiesen werden. Die Analyse dieses Effekts kann dazu verwendet werden, um a) die räumliche und zeitliche Repräsentanz von meteorologischen Stationen zu beurteilen, b) Spuren menschlicher Betätigung in schneebedecktem, ebenem Terrain aus Temperaturabbildungen niedriger Auflösungsgenauigkeit festzustellen, die von zukünftigen Satelliten geliefert werden, und c) den Umweltseinfluß arktischer Bauwerke abzuschätzen. 


\section{Introduction}

In a paper presented at the Fifth Symposion on Remote Sensing of Environment, Horvath and Lowe [3] presented thermal imagery collected over sea ice and snow covered tundra terrain in the vicinity of Point Barrow, Alaska during October, 1967. Among these images were relatively warm thermal plumes extending downwind from unheated buildings and oil drum dumps (see Fig. 1). The

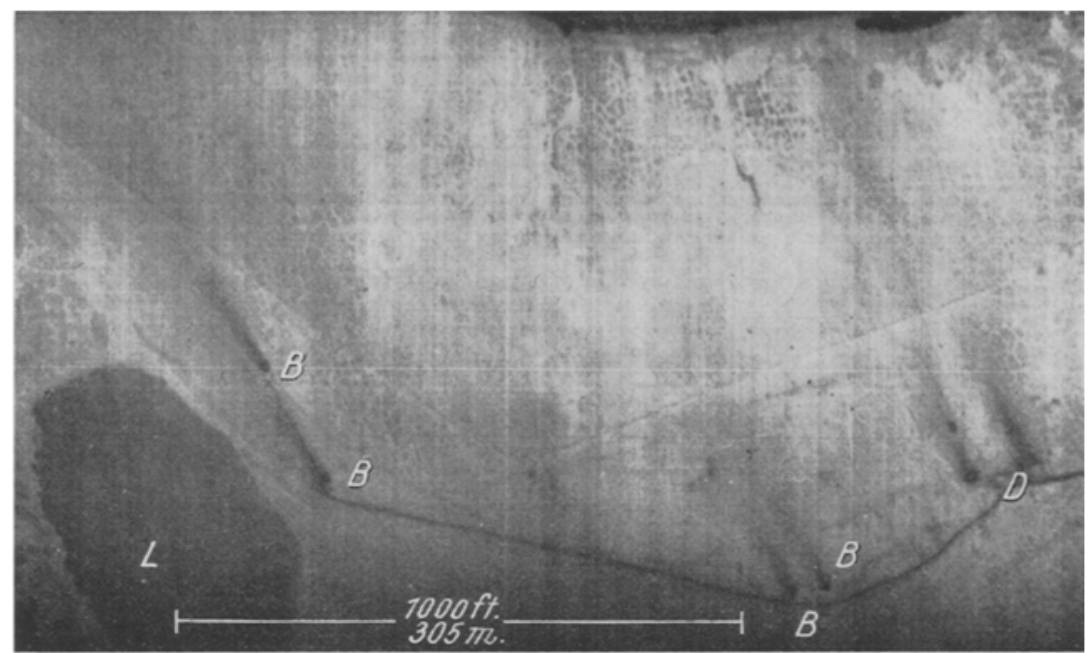

Fig. 1. Thermal imagery aquired south of the NARL site, Barrow, Alaska, 1715 AST, Oct. 11, 1967. Dark(hot), light(cold). Note, the warm plumes extending to the lee of the drum dumps $(D)$ and unheated buildings $(B)$ along the service road which is relatively warm compared to the snowcovered tundra surface. Snowcovered frozen lakes $(L)$ and low-center polygons also appear to be relatively warm

imagery, acquired at approximately 1700 solar time demonstrated that the warm plumes were at least two orders of magnitude longer than the heights of the obstructions producing them. The authors indicated that these features were the products of an "increase in the convective heat transfer coefficient which thermally couples the air to the tundra surface". If their hypothesis is correct a surface climate simulator should be capable of reproducing these effects, their sign and relative magnitude, with a minimum of environmental information. The remainder of this paper will describe that simulation and explore the implications of the "thermal plume effect". 


\section{Background}

Layered substrates are common in natural soils, snow and ice. Analytical solutions for substrate thermal regimes within layered media have previously been treated as variations of the general solution to the period heat flow problem and/or utilized measured surface or sub-surface thermal regimes as model forcing functions $[5,12,8]$. Unfortunately these solutions are of limited utility in assessing the ecological impact of surface manipulation as their thermal forcing functions are in nature the result of forefeed-feedback effects produced by the entire set of site optical, thermal and aerodynamic properties as they guide the evolution of the surface energy transfer regime. More specifically, the surface of substrate thermal regimes are the explicit results of site physical properties interacting with local weather and are thus more appropriately viewed as output rather than input functions. Recently there has been accelerating interest in the possibility of extracting environmental information from the spatial and temporal variability in surface thermal regimes [1]. The capability of modeling the system should be of some aid in this task.

\section{The Layered-Substrate Simulator}

As an extension of earlier-research on the simulation of diurnal needle ice growth and ablation at Vancouver, British Columbia, a surface climate simulator based on equilibrium temperature theory has been modified to incorporate variations of substrate thermal properties with depth [9]. The layered model employs an iterative solution of the Fickian diffusion equation over a grid of one-dimensional points with prescribed thermal properties. Thus, the upper limit of stratigraphic layers which can be simulated is determined by the number of points in the substrate grid which in turn is constrained by the numerical stability modulus of the layer with the largest thermal diffusivity and the selection of the computation time increment [4]. In practice the grid spacing is in the realm of $5 \mathrm{~cm}$ for common soils when an iteration increment of 15 minutes is selected. Detailed accounts of the development and application of the generalized surface climate simulator are available in the literature $[9,10,11]$. Lastly, an isothermal level or layer may be simulated by setting temperatures at and below that level to the ice point thereby constraining the evolution of the subsurface thermal regime. The "plume" analysis which follows will illustrate the potential of the model. 


\section{Thermal Plume Simulation}

Thermal plumes are illustrated extending downwind from unheated structures [approximate dimensions: $5(L) \cdot 5(W) \cdot 2.5(H) m$ ] and an oil drum dump [3]. These plumes can be identified in the imagery at least $250 \mathrm{~m}$ ( 800 feet) or two orders of magnitude longer than the height of the unheated structures (see Fig. 1).

In an attempt to simulate these effects the layered version of the simulator was utilized in conjunction with readily available environmental data $[2,3,7]$ and published estimates of roughness characteristics and soil thermal properties $[6,5]$.

Table 1. Input Data for Wake Simulation

Latitude $=71.3^{\circ} \mathrm{N}$

Station pressure $=1013 \mathrm{mb}$

Atmospheric dust content $=0.2$ part ice

Short wave albedo $=0.62$

Mean diurnal air temperature $=-12^{0} \mathrm{C}$

Radiant temp. of the sky hemisphere $=-40^{\circ} \mathrm{C}$

Active layer depth $=29 \mathrm{~cm}$

Solar declination $=-8.8^{\circ}$

Precipitable water $=6 \mathrm{~mm}$

Orbital radius vector $=.9966$

Infrared emissivity $=0.95$

Mean air rel. hum. $=95 \%$

C Surface wet fraction $=1.00$

Mean diurnal wind vel. $=3 \mathrm{~m} / \mathrm{sec}$.

\begin{tabular}{|c|c|c|c|}
\hline Stratigraphy & Depth & Diffusivity (c.g.s. $)^{1}$ & Vol. heat cap. (c.g.s.s. \\
\hline Snow (packed drift) & $0-9$ & 0.0038 & 0.16 \\
\hline Frozen organic layer & $9-19$ & 0.0125 & 0.36 \\
\hline Icy silt $\ldots \ldots \ldots \ldots$ & $19-$ & 0.0120 & 0.50 \\
\hline
\end{tabular}

Roughness length ${ }^{2}$ : Snow covered Tundra $=1 \mathrm{~cm}$., Plume $=100 \mathrm{~cm}$.

1 [5] and others, ${ }^{2}[6]$ and others.

Two simulations were run in which only the roughness length was altered to simulate contrast in the plume (see Tab. 2).

Table 2. Simulation Results ${ }^{1}$

\begin{tabular}{lrllllll}
\hline $\begin{array}{l}\text { Solar time } \\
\text { (hr.) }\end{array}$ & $\begin{array}{l}\text { Net solar } \\
\text { radiation } \\
\text { (mly/min) }\end{array}$ & $\begin{array}{l}\text { Net radiation } \\
\text { (mly/min) }\end{array}$ & $\begin{array}{l}\text { Soil heat } \\
\text { flux } \\
\text { (mly/min) }\end{array}$ & $\begin{array}{l}\text { Sensible } \\
\text { heat flux } \\
\text { (mly/min) }\end{array}$ & $\begin{array}{l}\text { Latent } \\
\text { heat flux } \\
\text { (mly/min) }\end{array}$ & $\begin{array}{l}\text { Surface } \\
\text { temperature } \\
\text { ('0) }\end{array}$ \\
\hline $00: 00$ & 0 & $(0)$ & $-109(-126)$ & $18(14)$ & $68(72)$ & $22(41)$ & $-16.2(-12.9)$ \\
$06: 00^{1}$ & 0 & $(0)$ & $-109(-126)$ & $18(14)$ & $68(72)$ & $22(41)$ & $-16.2(-12.9)$ \\
$09: 00$ & $25(25)$ & $-87(-102)$ & $13(13)$ & $56(53)$ & $19(36)$ & $-15.4(-12.6)$ \\
$12: 00$ & $75(75)$ & $-47(-55)$ & $9(12)$ & $26(18)$ & $12(25)$ & $-13.6(-12.2)$ \\
$15: 00$ & $25(25)$ & $-89(-102)$ & $21(15)$ & $51(52)$ & $18(36)$ & $-15.1(-12.6)$ \\
$17: 00^{2}$ & $0(0)$ & $-109(-127)$ & $22(15)$ & $66(70)$ & $21(41)$ & $-16.0(-12.9)$ \\
$21: 00$ & 0 & $(0)$ & $-109(-126)$ & $19(14)$ & $68(72)$ & $22(41)$ & $-16.2(-12.9)$
\end{tabular}

1 A flux vector is positive if directed toward the surface from either above or below

2 Time of thermal image acquisition

() Values computed for plume directly in building lee 
The simulated energy transfer regime dislocations produced by the buildings in the proximal sectors of the lee plume are highlighted in Tab. 3 .

Table 3. Simulated Plume-Tundra Contrast ${ }^{1}$

\begin{tabular}{llllll}
\hline $\begin{array}{l}\text { Solar time } \\
\text { (hr.) }\end{array}$ & $\begin{array}{l}\Delta \text { Net radiation } \\
\text { (mly/min) }\end{array}$ & $\begin{array}{l}\Delta \text { Soil heat flux } \\
\text { (mly/min) }\end{array}$ & $\begin{array}{c}\text { A Sensible heat } \\
\text { flux (mly/min) }\end{array}$ & $\begin{array}{c}\Delta \text { Latent heat } \\
\text { flux (mly/min) }\end{array}$ & $\begin{array}{c}\Delta \text { Surface } \\
\text { temperature } \\
\left({ }^{0} \mathrm{C}\right)\end{array}$ \\
\hline $06: 00$ & -18 & -4 & +4 & +18 & +3.3 \\
$09: 00$ & -15 & 0 & -3 & +18 & +2.8 \\
$12: 00$ & -8 & +3 & -8 & +13 & +1.4 \\
$15: 00$ & -12 & -7 & +1 & +18 & +2.5 \\
$17: 00^{2}$ & -18 & -6 & +4 & +20 & +3.1 \\
$21: 00$ & -18 & -4 & +4 & +18 & +3.3
\end{tabular}

1 Integer flux values corrected for rounding errors.

${ }^{2}$ Time of thermal image acquisition.

The simulation indicates that a thermal plume could be produced by increased obstacle roughness under the assumed boundary conditions. The plume formation appears primarily due to increased turbulent flux which is physically reasonable as the atmospheric exchange coefficient varies directly with surface roughness and wind velocity. In addition, as the surface temperature appears in all the components of the energy transfer equation all components are dislocated to some degree in the equilibrium solutions for the plume. Further, at the approximate time of the scan the plume contrast has the correct direction and is of a magnitude easily detectable in thermal imagery. Thus, the simulation strongly endorses the hypothesis of Horvath and Lowe [3].

\section{Implications}

This analysis demonstrates vividly the potential exploitation of the thermal plume effect in the analysis of the spatial-temporal integrity of meteorological and other environmental measurement sites. The thermal imagery indicates that the "scalling-up" effect of the thermal plume may facilitate the recognition of cultural features two orders of magnitude below the resolution threshold of spacecraft thermal imaging systems when environmental conditions are appropriate. Lastly, this work strongly implies that the construction of a large-diameter-above-surface-pipeline will produce similar effects in other smooth Arctic terrain. A long term plume effect may produce substrate thermal and active layer depth gradients, sub- 
normal to the surface, across pipeline support structures at locations where the prevailing wind system produces an annually significant spatially-temporally asymmetrical thermal wake effect.

\section{Conclusions}

Significant variations in the diurnal surface thermal regime are introduced by Arctic construction in flat snow covered terrain. It is of prime importance to determine if these effects which are pronounced on a diurnal time scale have significant annual impact. The plume effect may have pronounced environmental effects on substrate thermal regimes even at locations which are defended against conduction and radiative heat transfer as the plume springs from increased roughness alone.

\section{Acknowledgements}

Special thanks are due R. Horvath of Willow Run Laboratories who was a great aid to the author in providing a first hand account of the field conditions at the time of thermal image acquisition. The imagery was obtained through a programme jointly sponsored by Willow Run Laboratories and the Arctic Institute of North America under contractual arrangements with the Office of Naval Research (ONR-426).

\section{References}

1. Holter, M. R., et al.: Research Needs ..., in: Remote Sensing. Committee on Remote Sensing for Agricultural Purposes, Agricultural Board, Nat. Res. Council, Nat. Acad. Sciences, Washington, D. C., 1970.

2. Horvath, R., and W. L. Brown: Multispectral Radiative Characteristics of Arctic Sea Ice and Tundra. Infrared and Optics Laboratory, Willow Run Laboratories, Inst. Science and Technology, University of Michigan, prepared for Arctic Inst. North America, Agreement ONR-426, 65 pp. (1971).

3. Horvath, R., and D.S. Lowe: Multispectral Survey in the Alaskan Arctic. Proc. Fifth Symposium on Remote Sensing of Environment, Infrared Physics Laboratory, Willow Run Laboratories, Inst. Science and Technology, University of Michigan, Ann Arbor, p. 483 -496 (1968).

4. Kreith, F.: Principles of Heat Transfer, p. 175-188. Scranton: Internat. Textbook Co., 1967.

5. Lachenbruch, A.H.: Periodic Heat Flow in a Stratified Medium with Application to Permafrost Problems. U. S. Geol. Survey Bull. 1083-A, 36 pp. (1959).

6. Lettau, H.: Note on Aerodynamic Roughness Parameter Estimation on the Basis of Roughness Element Description. J. App. Met. 8, 828-832 (1969).

7. Mather, J. R., and C. W. Thornthwaite: Microclimatic Investigations at Point Barrow, Alaska, 1957-1958. Publ. in Climatology, Drexel Inst. of Tech., Laboratory of Climatology, Vol. XI, No. 2, Centerton, New Jersey, 239 pp,. (1958). 
8. Nakano, Y., and J. Brown: Mathematical Modeling and Validation of the Thermal Regimen in Tundra Soils, Barrow, Alaska. Arctic and Alpine Research 4, 19-38 (1972).

9. Outcalt, S.: A Numerical Surface Climate Simulator. Geographical Analysis III, 379-392 (1971).

10. Outcalt, S.: The Climatonomy of a Needle Ice Event. Arch. Met. Geoph. Biokl., B, 19, 325-330 (1971).

11. Outcalt, S.: The Development and Application of a Simple Digital Surface Climate Simulator. Jour. App. Met. 11, 629-636 (1972).

12. Van Wijk, W. R., and J. Derksen: In: The Physics of Plant Environment, 382 pp. Amsterdam: North-Holland Publishing Co., 1966.

Author's address: Dr. Sam I. Outcalt, Department of Geography, University of Michigan, Ann Arbor, MI 48104, U.S. A. 